\title{
Can The Prices Of The World Crude Oil As A Proxy Cost Transportation In Trade In Asean-3?
}

\author{
Lumadya Adi ${ }^{1}$ \\ ${ }^{1}$ Faculty of Economics, DR. Soetomo University - Surabaya \\ E-mail: adios_ulin@yahoo.com
}

\begin{abstract}
The purpose of this paper is to examine the effect of crude oil prices, GDPimporter, and GDPexporter on trade in three ASEAN includes: Indonesia, Malaysia, and Thailand. In this context, the three ASEAN countries are assumed to be trading partner for two advanced countries, namely USA and Japan.To reach research purposes, this paper uses quantitative research method. As analysis technique, econometrics is being applied which consists of two ways: Ordinary Least Squares (OLS) and Panel Data. The results show that GDP exporter countries, GDP importer countries and crude oil price have significant and positive impact to trade value
\end{abstract}

Keywords: crude oil price, GDPexporters, GDPimporters, trade

JEL Classification: F10, F14

\section{INTRODUCTION}

Trade has long been committed by citizens of a country with citizens of other countries. The purpose of trade is to equally benefit from such acti-vities. Countries that have more exports than imports means the country receives income (surplus), but a country whose exports less imports will lose foreign exchange (deficit).

Many factors could affect trade (exports plus imports) of a country. The GDPexporter and GDPimporter referred to as the main factors that affect the trade from one country to another countries. In addition, the distance between the two countries said to be a major factor in the trade. The relationship distance with trade is a ne-gative correlation: when distance is long distance that will trade a little, when the distance is closer then the trade will increase.
Newton's gravitational theory is used in economics seek to answer about the role of size of economy (income countries, GDP) and distance in explaining the phenomenon of trading. In this paper, researcher did not include distance as a proxy for transportation costs but researcher replace it with the prices of crude oil which researcher believe is a proxy that is more appropriate to describe the magnitude of transportation costs for transport always wear an oil component in a range of derivatives in addition to taking into account the distance.

The prices of crude oil fluctuates from time to time, there are times when riding high once but once prices fall dramatically due to various events that preceded it, generally the state of the world economy and political factors. 
The prices of the world crude o-il per barell can be look at this table

Table 1

The prices of the world crude oil

In 2000-2014 (USD per barell)

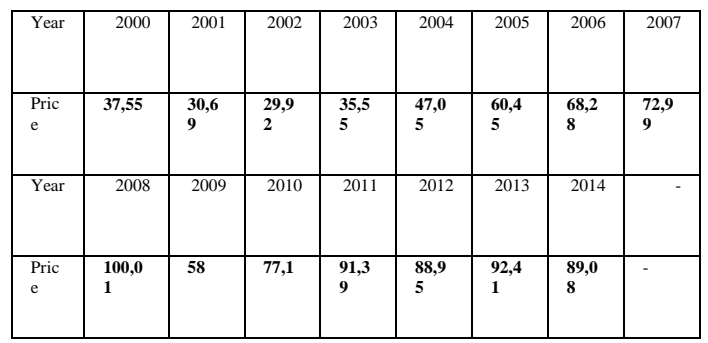

Source: www.wikipedia/harga minyak mentah dunia

From Table 1 we know that price of the world crude oil is above the average for 2005 increased steadily until 2008 with a value of \$ 100.01 per barrel and then fell to 58 USD per barell in 2009. In 2008 and 2009 there was the world economic crisis started from the United States and then spread to Europe and eventually the world. In the last two years (2013 and 2014) prices of crude oil was decline.

Alleyne and Lorde (2014) conducted a study of trade for the member countries of CARICOM and conclusion: differences in GDP per capita, the ratio of trade to GDP and language positive effect on trade, while the geographical distance, the excha-nge rate and the unexpected, the his-torical relationship of trade had a negative effect on trade. Another result is a variable exchange rate is very imp-ortant and CARICOM member coun-tries would be better if the trade with countries that have a higher standard of living.

Rely on these backgrounds the paper generates some research problems namely:
Do GDPexporter, GDPimport$\mathrm{er}$, and prices of crude oil influence significantly to trade in Indonesia? Do GDPexporter, GDPimport-er, and pric-es of crude oil influence significantly to trade in in Malaysia? Do GDPexporter, GDPimporter, and prices of crude oil in-fluence significantly to trade in Th-ailand?

\section{THEORETICAL FRAMEWO- RK AND HYPOTHESES}

The literature review begins with Newton writing in the journal Philosophie Naturalis Principia Mathe-maatica (Wikipedia Indonesian; Alleyne and Lorde (2014); Binh et al (.); Rahman (2009) on gravity using the formula:

$$
\mathbf{F}=\mathbf{G} \frac{m 1 \cdot m i}{r 2}
$$

Where: $\mathrm{F}$ is the great force of gravity between $\mathrm{m} 1$ and $\mathrm{m} 2 ; \mathrm{G}$ is the gravitational constant; $\mathrm{m} 1$ is the mass of the first object; $\mathrm{m} 2$ is the mass of the second object; $r$ is the distance between multiple $\mathrm{m} 1$ and $\mathrm{m} 2$. The essence of Newton's gravitational force is mass $\mathrm{ml}$ will always have attractive forces with other mass, $\mathrm{m} 2$ and is inversely related to the square of the distance between $\mathrm{m} 1$ and $\mathrm{m} 2$.

The first author, Jan. Tienbergen (1962) in Rauch (2015: 1) uses gravity equation in economics with models:

$$
\mathrm{E}_{\mathrm{ij}}=\alpha_{0} Y_{i}^{\alpha 1} Y_{j}^{\alpha 2} D_{i j}^{\varepsilon 3}
$$

where: Eij is export from country $i$ to $\mathrm{j}$; Yi showed GNP state $\mathrm{i}$; Yj shows GNP state $\mathrm{j}$; D show the distance between country $i$ and country $j$; Estimates of the value of $\alpha 1, \alpha 2$ approaching $\alpha 3+1$ and the estimated value close to -1 .

Anderson (2014) argues the role of trade in national income in the 
calculation of economic size: if the ratio Trade/GDP is large will lead to small economic size, whereas if the ratio of Trade/GDP is small it will lead to large economic size.

Anderson (2014) said in a trade many cost components other than the cost of transport. Other costs (dark cost) include: information cost, nonmonetary barrier-regulating, licensing, taste differences, extortion, inscure contract.

Donaldson (2011) said that in addition to the transportation cost there are also the cost of trade. Total trade cost are all expenses incurred from the beginning to the goods and services reached the destinations. These costs include: tariff and nontariff barriers (quotas, etc), transportation cost, ad-ministration hurdles, corruption, contrac-tual frictions, the need to secure trade finance (working capital goods while in transit).

Distance in gravity models is a proxy of transportation costs. Transportation costs can be broken down into two (2) (see Prentice et al (1998) in Vido and Prentice (2003: 127, 128); (Saddam and Kari, 2012: 155) that the cost of transport by sea (marine transport Gravity Models) and cost of transport by land (land transport Gravity Models).

Bhattacharyya and Banerje (2006) investigated the trade in India with gravity models. Research results: (1). The role model of gravity is able to explain 43 percent of India's trade fluctuation during the 21 st century, (2). Response India trade smaller proportion to the size of the economy and a greater proportion to the distance, (3). Colonial heritage is still an important factor for the trade of India during the 19th century, (4). India trade better with negra advanced when compared to the less developed countries, and (5). The size of the economy affecting trade in India when compared to countries such trading partner.

Marimoutou et al (2010) studied the behavior of national income (GDP) and distance (DISTANCE) to export to the gravity models. The final conclusion: national income are positive and significant impact on exports, whereas the distance significant and negative effect.

Xuan Bac Nguyen (2010) in Dinh et al (.) Uses gravity model of research on Vietnamese exports during the last 20 years by the year 2006 with the export as dependent variable, while the independent variables are GDP, distance, average real exchange rate and a dummy variable ASEAN mem-bership. Research results: the value of Vietnamese exports to other countries positively influenced by GDP, exchange rate, and the membership of ASEAN; adversely distance a negatif influence on Vietnamese exports.

\section{RESEARCH METHOD}

\section{Data and data sources}

The data used in this research is secondary data obtained from www.asian development bank, org / statistics / key indicators for asia and the pacific in 2015 with the observation period from 2000 to 2014; www.world indicatos.org development; www-.world-bank.org.

There are five countries surveyed, namely Indonesia, Malaysia, Thailand, USA and Japan. Indonesia, Malaysia, Thailand is ASEAN members-3, while the USA and Japan are outside ASEAN. USA and Japan participated observed because both countries are major trading partners are the ASEAN-3. 
Year 2000 as the be-ginning of the data examined the grou-nds starting in 2000 the economy is back to normal after three countries (Indonesia, Malaysia, Thailand) experienced a financial crisis, while the latest data surveyed in 2014 because of the availability of data.

\section{Research Variables}

Trade (LNTRADE)

Trade is exports plus imports of a country. The value initially in USD fo$\mathrm{rm}$ then transformed into Natural Logarithm (Ln).

Gross Domestic Product (LNGDPimporter)

Gross Domestic Product is the income of a country importers that import (countries whose trade as independent variables). The value initially in USD form then transformed into Natural Logarithm (Ln).

Gross Domestic Product (LNGDPexporter)

Gross Domestic Product is the income of a country exporters who export (to a country whose trade as independent variables). The value initially in USD form then transformed into Natural Lo-garithm (Ln).

The Prices of the World Crude Oil (LNOPEC)

The Prices of the World Crude Oil is the price of crude oil which is managed by the World Organization of Petro-leum Producers (OPEC). The value initially in USD per barrel form then transformed into Natural Logarithm (Ln).

\section{Model}

The model used in this study are:

1).Gravity models as follows:
Initial formula by Jan Tienbergen (1962) in Rauch (2015: 1) used the equation:

$$
\mathrm{E}_{\mathrm{ij}}=\alpha_{0} Y_{i}^{\alpha 1} Y_{j}^{\alpha 2} D_{i j}^{\varepsilon 3}
$$

if written in a linear equation then:

$$
\begin{aligned}
& \mathrm{LN}(\mathrm{Eij})=\boldsymbol{\alpha} 0+\boldsymbol{\alpha} \mathbf{1} \mathrm{Ln}(\mathrm{Yi})+\boldsymbol{\alpha} \mathbf{2} \mathrm{Ln} \\
& (\mathrm{Yj})-\boldsymbol{\alpha} \mathbf{3} \operatorname{Ln}(\mathrm{D})+\varepsilon \mathbf{i j}+\mathrm{e}_{\mathrm{ab}}
\end{aligned}
$$

The formula is used a modified model (2) by substituting the distance (D) with the price of crude oil (OPEC) so that its becomes:

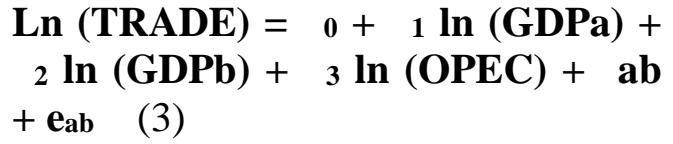

Where Ln (Trade) is Ln (Exports + Imports); Ln (GDPa) is $\mathrm{Ln}$ (GDPexporter); Ln (GDPb) is $\mathrm{Ln}$ (GDPimporter); Ln (OPEC) is Ln (prices of crude oil, OPEC); $\varepsilon a b$ is $u_{a}$ $+\mathrm{v}_{\mathrm{b}}+\mathrm{w}_{\mathrm{ab}}$ and $\mathrm{e}_{\mathrm{ab}}$ is residual; $\beta_{0}=$ consta-nt; $\beta_{2}, \beta_{1}$ is the regression coefficient of the expected value $>0$; $\beta_{3}$ is expected regression coefficient value $<0$.

\section{DATA ANALYSIS AND DISCUSSION}

The following is figure from the five countries GDP from the year 2000-2014:

Figure 1

GDP countries is Analyzed Years 2000-2014 (Billion USD)

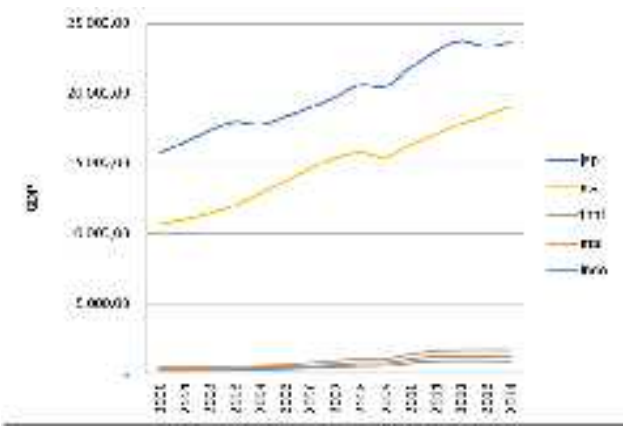

Source:www.adb.org/statistic/key indicators for asia and the pacific 2015, proceed 
From Figure 1 we see that the GDP of Japan and the United States are very high when compared with the three ASEAN countries (Indonesia, Malaysia, Thailand). We also see that trend GDP of the three countries all increased. GDP rise in the exporting and importing countries would lead to an increase in trade.

All the variables to be analyzed must be tested first to see if the data has been stationary at I (0), I (1), I (2) or even stationary. If the data is stationary at level, I (0) then it could dilanjutkn to be analyzed with static data panel, but if the data is stationary I (1) or I (2) should be done with dynamic panel data. There are many options for analyzing stasionaritas but in the current study researchers used a model Hadri.

Result of stationary panel data test with Hadri model can be look at this table:

Table 1

Summary of Result Analysis Panel data Unit Root with Hadri Model

Research Variables in ASEAN-3

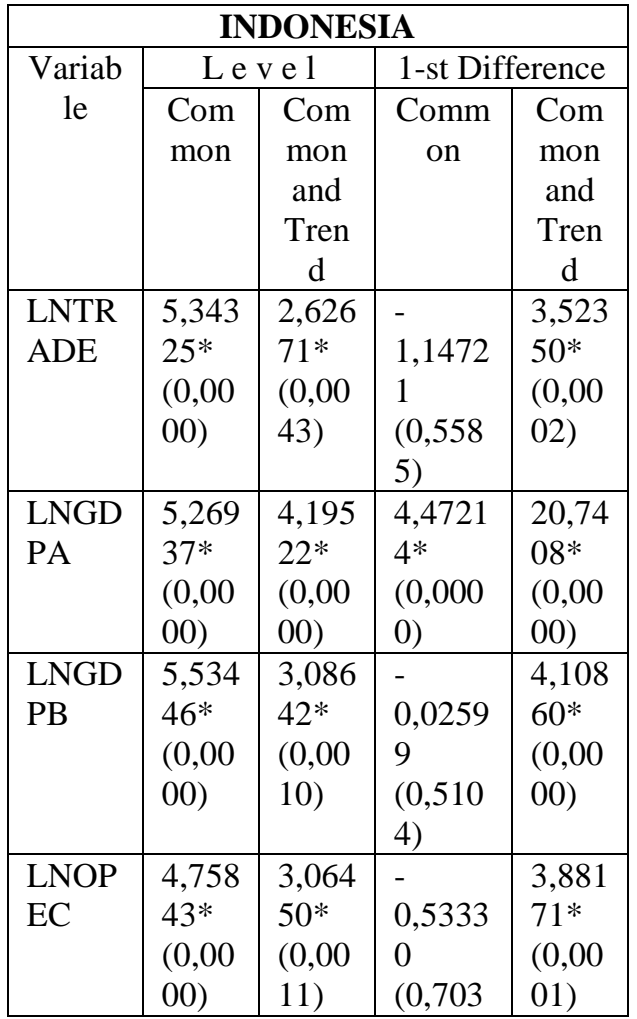

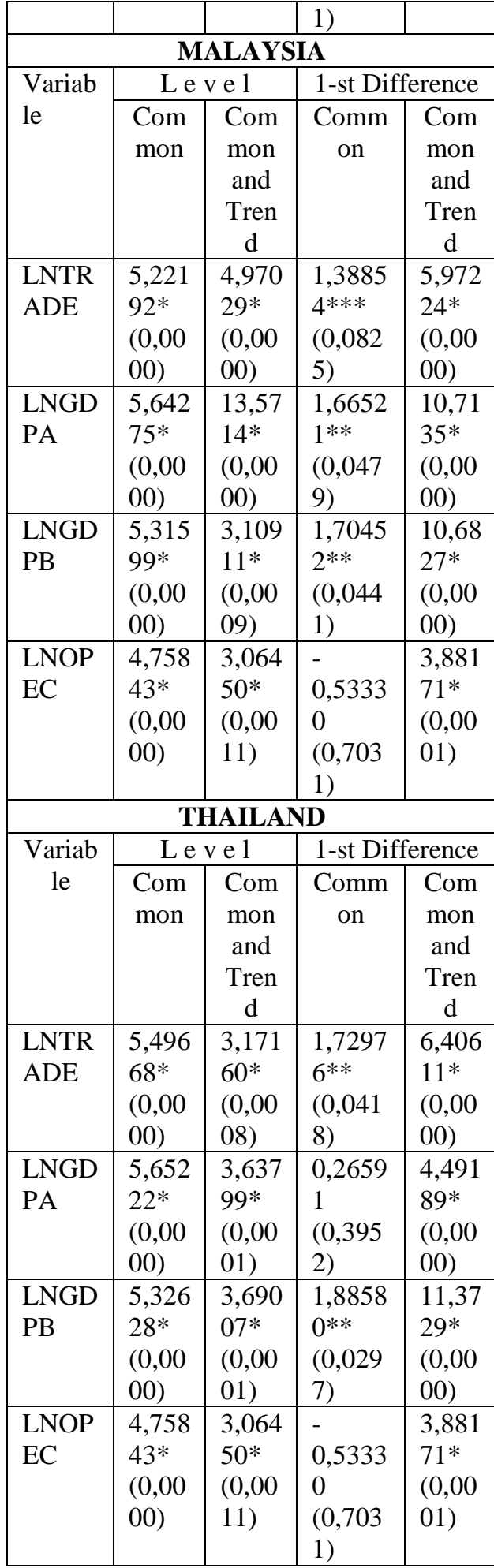

Source: www.adb.org/statistic/key indicators for asia and the pacific 2015, proceed

Note: $\quad *$ significant in $1 \%$; ** significant in $5 \%$; $\quad * * *$ significant in $10 \%$

Unit root test results of four research variables in Table 1 shows: to Indonesia (in level: common or com- 
mon and trend) variables: LNTRADE, LNGDPa, LNGDPb, and LNOPEC are stationary; to Malaysia (in level: com-mon or common and trend) variables LNTRADE, LNGDPa, $\mathrm{LNGDPb}$ and LNOPEC are stationary; to Thailand (in level: common or common and tre-nd) variables: LNTRADE, LNGDPa, LNGDPb, and LNOPEC are stationary. All variables proved to have passed the test stationary so that analysis of data can be forwarded to the static panel data.

Summary of the results of OLS and FEM analysis for Indonesia:

Table 2

Summary of OLS and the FEM Trading in Indonesia

\begin{tabular}{|c|c|c|c|c|}
\hline \multirow[t]{2}{*}{ Variable } & \multicolumn{2}{|c|}{ OLS } & \multicolumn{2}{|c|}{ FEM } \\
\hline & $\begin{array}{l}\text { Coef } \\
\text { ficie } \\
\text { nt }\end{array}$ & $\begin{array}{l}\text { t-test } \\
\text { (signifi } \\
\text { cance) }\end{array}$ & $\begin{array}{l}\text { Coeffi } \\
\text { cient }\end{array}$ & $\begin{array}{l}\text { t-test } \\
\text { (signifi } \\
\text { cance) }\end{array}$ \\
\hline \multirow[t]{2}{*}{ Constant } & 4,21 & 1,24186 & 2,636 & 0,77955 \\
\hline & 8507 & 4 & 725 & 4 \\
\hline \multirow[t]{2}{*}{ LNGDPA } & 0,35 & 2,14539 & 0,400 & 2,40098 \\
\hline & 8114 & $2 * *$ & 364 & $3 * *$ \\
\hline \multirow[t]{2}{*}{ LNGDPB } & 0,25 & 9,81171 & 0,258 & 10,0178 \\
\hline & 6663 & $8^{*}$ & 688 & $5 *$ \\
\hline \multirow[t]{2}{*}{ LNOPEC } & 0,57 & 1,89842 & 0,656 & 3,42988 \\
\hline & 2908 & $4 * * *$ & 435 & $4 *$ \\
\hline 1. Mal & & & $\begin{array}{r}1,577 \\
641\end{array}$ & \\
\hline 2. Thai & & & $\begin{array}{r}0,999 \\
187\end{array}$ & \\
\hline \multirow[t]{3}{*}{ 3. USA } & & & - & \\
\hline & & & 2,010 & \\
\hline & & & 204 & \\
\hline \multirow[t]{3}{*}{ 4. Japan } & & & - & \\
\hline & & & 0,566 & \\
\hline & & & 623 & \\
\hline Observasi & $n=$ & & $n=60$ & \\
\hline & & & & \\
\hline \multirow[t]{2}{*}{$\mathrm{R}^{2}$} & 0,79 & & 0,853 & \\
\hline & 7287 & & 886 & \\
\hline \multirow[t]{2}{*}{$\mathrm{R}^{2}$ Adjusted } & 0,78 & & 0,846 & \\
\hline & 6427 & & 053 & \\
\hline \multirow[t]{2}{*}{ F-test } & 73,4 & & 109,0 & \\
\hline & 1746 & & 871 & \\
\hline \multirow{2}{*}{$\begin{array}{l}\text { S.E. of } \\
\text { regression }\end{array}$} & 0,38 & & 0,386 & \\
\hline & 7051 & & 203 & \\
\hline DW & $\begin{array}{r}0,27 \\
2844\end{array}$ & & & \\
\hline
\end{tabular}

\begin{tabular}{|l|l|r|r|}
\hline Likelihood & & 68,65 & \\
Ratio & & 1828 & \\
\hline
\end{tabular}

Source:www.adb.org/statistic/key indicators for asia and the pacific 2015, analyzed

Note: $\quad *$ significant in $1 \%$; $* *$ significant in 5\%; $\quad * * *$ significant in $10 \%$

From Table 2 (Indonesia) we see that the OLS model analysis resulted in the conclusion that the variable income exporting countries (LNGD$\mathrm{Pa}$ ), income importing countries (LN$\mathrm{GDPb}$ ), and the price of crude oil (LN-OPEC) positive and significant impact on trade (LNTRADE). The regression coefficient world crude oil prices (LN-OPEC) is positive not as expected. Variations were able to explain the va-riables of $79.73 \%$, while the remaining $20.27 \%$ is explained by other var-iababel outside the model.

Still on Table 2 we see that the FEM model analysis resulted in the conclusion that the variable income exporting countries (LNGDPa), income importing countries (LNGDPb), and the price of crude oil (LNOPEC) positive and significant impact on trade (LNTRADE). The regression coeff-icient world crude oil prices (LNO-PEC) is positive not as expected. Varia-tions were able to explain the variables of $85.39 \%$, while the remaining $14.61 \%$ is explained by other variables outside the model.

The findings by the FEM stating economic size positive and significant effect on trade supports previous findings from Alleyne and Lorde (2014), Bhattacharyya (2006), Marimoutou (2010), Bac Xuan Nguyen (2010) in Dinh et al (.). Variations are able to be explained by the prices of crude oil and its economic size Indonesia with trading partner countries amounted to $85.39 \%$. The magnitude of the variation is much higher than 
the findings of the trade in India for the 21 st century with a gravity model that is only $43 \%$.

Summary of the results of OLS and FEM analysis for Malaysia:

Table 3

Summary of OLS and the FEM Trading in Malaysia

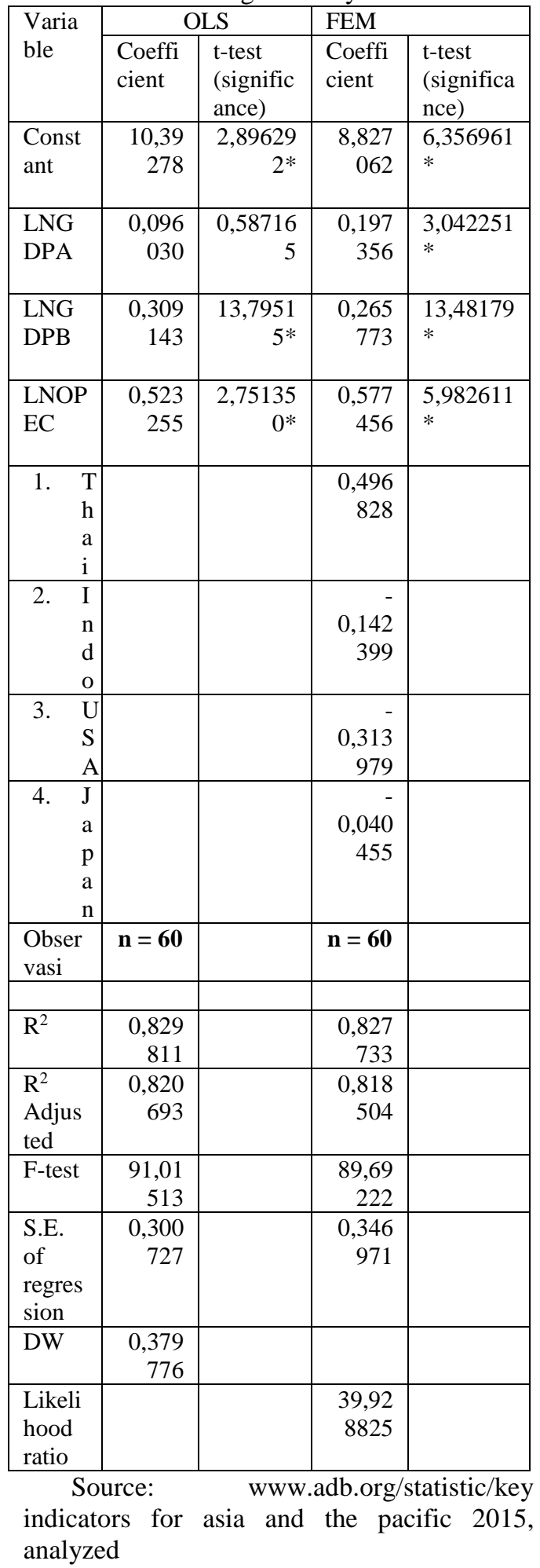

Note: $\quad *$ significant in $1 \%$; $* *$ significant in 5\%; $\quad * * *$ significant in $10 \%$

From Table 3 (Malaysia) we see that the OLS model analysis resulted in the conclusion that the variables: income importing countries (LNG-DPb), and the price of crude oil (LNOPEC) positive and significant impact on trade (LNTRADE), but income exporting countries (LNGDPa) positive and not significant impact. The regression coefficient world crude oil prices (LNOPEC) is positive not as expected. Variations were able to explain the variables of $82,98 \%$, while the remaining $17,02 \%$ is explained by other variables outside the model.

Still on the Table 3 we see that the FEM model analysis resulted in the conclusion that the variable income exporting countries (LNGDPa), inco-me importing countries (LNGDPb), and the price of crude oil (LNOPEC) positive and significant impact on trade (LNTRADE). The regression coefficient world crude oil prices (LNOPEC) is positive not as expected. Variations were able to explain the variables of $82.77 \%$, while the remaining $17.23 \%$ is explained by other variababel outside the model.

The findings by the FEM stating economic size positive and significant effect on trade supports previous findings from Alleyne and Lorde (2014), Bhattacharyya (2006), Marim-outou (2010), Bac Xuan Nguyen (2010) in Dinh et al (.). Variations are able to be explained by the price of crude oil and its economic size Malaysia with trading partner countries amounted to $82.77 \%$. The magnitude of the variation is much higher than the findings of the trade in India for the 21 st century with a gravity model that is only $43 \%$. 
Summary of the results of OLS and FEM analysis for Thailand:

Table 4

Summary of OLS and the FEM

Trading in Thailand

\begin{tabular}{|c|c|c|c|c|}
\hline \multirow[t]{2}{*}{ Variable } & \multicolumn{2}{|c|}{ OLS } & \multicolumn{2}{|c|}{ FEM } \\
\hline & $\begin{array}{l}\text { Coefi } \\
\text { cient }\end{array}$ & $\begin{array}{l}\text { t-test } \\
\text { (signifi } \\
\text { cance) }\end{array}$ & $\begin{array}{c}\text { Coefic } \\
\text { ient }\end{array}$ & $\begin{array}{l}\text { t-test } \\
\text { (signifi } \\
\text { cance) }\end{array}$ \\
\hline Constant & $\begin{array}{r}0,320 \\
432\end{array}$ & $\begin{array}{r}0,0387 \\
33\end{array}$ & $\begin{array}{r}1,671 \\
984\end{array}$ & $\begin{array}{r}0,5809 \\
89\end{array}$ \\
\hline LNGDPA & $\begin{array}{r}0,542 \\
927\end{array}$ & $\begin{array}{r}1,4540 \\
79\end{array}$ & $\begin{array}{r}0,426 \\
168\end{array}$ & $\begin{array}{r}3,4488 \\
64 *\end{array}$ \\
\hline LNGDPB & $\begin{array}{r}0,278 \\
372\end{array}$ & $\begin{array}{r}8,9569 \\
54 *\end{array}$ & $\begin{array}{r}0,330 \\
414\end{array}$ & $\begin{array}{r}31,993 \\
33^{*}\end{array}$ \\
\hline LNOPEC & $\begin{array}{r}0,322 \\
266\end{array}$ & $\begin{array}{r}0,8227 \\
79\end{array}$ & $\begin{array}{r}0,440 \\
929\end{array}$ & $\begin{array}{r}3,5743 \\
33 *\end{array}$ \\
\hline $\begin{aligned} 1 . & \mathrm{M} \\
& \mathrm{a} \\
& 1\end{aligned}$ & & & $\begin{array}{r}0,470 \\
772\end{array}$ & \\
\hline $\begin{array}{ll}2 . & \mathrm{I} \\
& \mathrm{n} \\
& \mathrm{d} \\
& \mathrm{o}\end{array}$ & & & $\begin{array}{r}- \\
0,401 \\
671\end{array}$ & \\
\hline $\begin{array}{rr}\text { 3. } & \mathrm{U} \\
& \mathrm{S} \\
\mathrm{A}\end{array}$ & & & $\begin{array}{r}- \\
0,442 \\
052\end{array}$ & \\
\hline $\begin{aligned} & \text { 4. } \mathrm{J} \\
& \mathrm{a} \\
& \mathrm{p} \\
& \mathrm{a} \\
& \mathrm{n}\end{aligned}$ & & & $\begin{array}{r}0,372 \\
951\end{array}$ & \\
\hline Observasi & $\begin{array}{l}n= \\
60\end{array}$ & & $n=60$ & \\
\hline $\mathrm{R}^{2}$ & $\begin{array}{r}0,720 \\
737\end{array}$ & & $\begin{array}{r}0,797 \\
418\end{array}$ & \\
\hline $\begin{array}{l}\mathrm{R}^{2} \\
\text { Adjusted }\end{array}$ & $\begin{array}{r}0,705 \\
777\end{array}$ & & $\begin{array}{r}0,786 \\
565\end{array}$ & \\
\hline F-test & $\begin{array}{r}48,17 \\
603\end{array}$ & & $\begin{array}{r}73,47 \\
696\end{array}$ & \\
\hline
\end{tabular}

\begin{tabular}{|l|r|l|r|l|}
\hline $\begin{array}{l}\text { S.E. of } \\
\text { regression }\end{array}$ & $\begin{array}{r}0,438 \\
4\end{array}$ & & $\begin{array}{r}0,457 \\
275\end{array}$ & \\
\hline DW & 0,097 & & & \\
794 & & & \\
\hline $\begin{array}{l}\text { Likelihood } \\
\text { ratio }\end{array}$ & & & 202,8 & \\
\hline
\end{tabular}

Source: www.adb.org/statistic/key indicators for asia and the pacific 2015, analyzed

Note: $\quad *$ significant in $1 \%$;

significant in 5\%; $\quad * * *$ significant in $10 \%$

From Table 4 (Thailand) we see that the model analysis OLS produ-ce a conclusion that the variable inco-me importing countries (LNGDPb) positive and significant impact on trade (LNTRADE), while the income of the exporting country (LNGDPa) and crude oil prices (LNOPEC) positive effect but not significant. The regre-ssion coefficient world crude oil prices (LNOPEC) is positive not as expected. Variations were able to explain the variables of $72.07 \%$, while the remaining $27.93 \%$ is explained by other variables outside the model.

Furthermore, still from Table 4 we see that the FEM model analysis resulted in the conclusion that the variable income exporting countries (LNGDPa), income importing countries (LNGDPb), and the price of crude oil (LNOPEC) positive and significant impact on trade (LNTRADE). The regression coefficient world crude oil prices (LNOPEC) is positive not as expected. Variations were able to explain the variables of $79.74 \%$, while the remaining $20.26 \%$ is explained by other variables outside the model. 


\section{CONCLUSION,IMPLICATION, SUGGESTION, AND LIMITATI- ONS}

For Indonesia: GDPexporter, GDPimporter, and the price of crude oil respectively positive and significant ef-fect on trade. The coefficient of crude oil prices is positive, not as expected in which the initial expectations are nega-tive. Variations are able to be explained by the price of crude oil and its economic size Indonesia with trading partner countries amounted to $85.39 \%$.

For Malaysia: GDPexporter, GDPimporter, and the price of crude oil respectively positive and significant effect on trade. The coefficient of crude oil prices is positive, not as expected in which the initial expectations are negative. Variations are able to be explained by the price of crude oil and its economic size Malaysia with trading partner countries amounted to $82.77 \%$.

For Thailand: GDPexporter, GDPimporter, and the price of crude oil respectively positive and significant effect on trade. The coefficient of crude oil prices is positive, not as expected in which the initial expectations are negative. Variations are able to be explained by the price of crude oil and its economic size Thailand with trading partner countries amounted to $79.74 \%$.

As the prices of the world cru-de oil can explain the behavior of inter-national trade so that could be used as an alternative to the distance variable. Researcher concerns to put new varia-bles for improve the model and general results.

\section{REFERENCES}

Alleyne, A. and Lorde, T. (2014), A Gravity Model Approach to Analyzing the Trade Performance of CARRICOM MEMBER STATES,
Applied Econo-metrics and International Develop-ment, Vol. 14-2 (2014), https://www-

.Researchgate.net/profile/Troy_Lorde/ publication/276270658_a_Gravity_M odelApproach_to_Analyzing the_trad e Performance of _CARRICOMM-ME MBER states /Link/55540c6d08ae6f d2d81f 3 da.pdff/ONLINE, accessed May 23, 2016.

Anderson, J.E. (2014), Trade, Size, and Frictions: The Gravity Model, Boston College and NBER, Januari 17, 2014, www2.bc.edu/anderson/Grvity/slides. pdf, ONLINE, accessed May 15, 2016.

Asian Development Bank, www.asian developmentbank.org/statistic/key indicators for asia and the pacific 2015.

Bhattacharyya, R. and Banerjee, T. (2006), Does the Gravity Model Explain India's Direction of Trade, Research and Publication, W.P., No. 2006-09-01, September 2006, Indian Institute of Management, Ahmedabad380-05,India,http://www.iimahd.ernet.in/publications/data/20062006-09-01 tathagata.pdf/ ONLINE, accessed May 23, 2016.

Binh, D.T.T, Duong, N.V., and Cuong, H.M. (.), Appling Gravity Model to Analysis Trade Activities of Vietnam, WorkingPaper, www.freit.org/working papers/papers/TradePatters/FREIT63 .pdf, ONLINE, accessed January 23, 2016.

Donaldson, D. (2011), Lecture 16: Gravity Models (Empirics), 14.581 MIT PhD International Trade, www.economics.mit.edu/files/7451,ONLIN E, accessed January 23, 2016.

Marimoutou, V., Peguin, D., and Feissole, P. (2010), The "DistanceVarying" Gravity Model in International Economics: Is the Distance an Obstacle to Trade? HAL ArchiveOurverses, Submited on 15 Nov 2010, http://halshs.archivesourvertes.fr/halhs -00536127, ONLINE, accessed Pebruary 05, 2016.

Rahman, M.M. (2009), Australia's Global Trade Potential: Evidence from the Grvity Model Analysis, Oxford Business and Economics Conference, 2009Oxford Business \& Economics Conference Program, St. 
Hugh's College, Oxford University, Oxford,UK, https://eprints.usq.edu.au/55371/Rahman_obec_09_PV.pdf, ONLINE, accessed Pebruary 24, 2016.

Rauch, F. (2015), The Geometry of the Distance Coefficient in Gravity Equations in International Trade, Oxford University, http://users.ox.ac.uk/ecom0360/FerdinandRauch/Bees. pdf/ONLINE, accessed January 23, 2016.

Saddam, A. and Kari, F. (2012), Size of Economy, Cost of Transport and Their Impact on Trade in GCC Countries: Evi-dence from Quality and Quantitative Approaches, ISSN: 2241-0988 (print version), 2241-0996 (online), Scienpress Ltd, 2012, Journal of Finance and Investment Analysis, Vol. 1, No. 3, 2012, 137-169, Kuala Lumpur, ONLINE, accessed January 23, 2016.

Vido, E. and Prentice, B.E. (2003), The Use of Proxy Variables in Economic Gravity: a Cautionairy Note, Journal of the Transportation Research Forum, Published in Transportation Quartely, Vol. 57, No. 1, Winter 2003 (123-137), http://www.unti.ca/media/docs/Proxy_ Var_Economic_Gravity_2003.pdf/ ONL̄INE, accessed May 23, 2016.

World Bank, www.world development indicators.org/2015 